\title{
УДК 378.1:61 \\ ОСОБЛИВОСТІ ВИКЛАДАННЯ БІОЛОГІЧНОЇ ХІМІЇ НА МЕДИКО- ПСИХОЛОГІЧНОМУ ФАКУЛЬТЕТІ НАЦІОНАЛЬНОГО МЕДИЧНОГО УНІВЕРСИТЕТУ ІМЕНІ О. О. БОГОМОЛЬЦЯ
}

\author{
І. В. Ніженковська, Л. В. Яніцька, О. В. Стеченко, М. С. Власенко, Т. П. Прадій \\ Національний медичний університет імені О. О. Богомольия
}

\section{THE FEATURES OF BIOLOGICAL CHEMISTRY TEACHING IN MEDICAL-PSYCHOLOGICAL FACULTY OF O. O. BOHOMOLETS NATIONAL MEDICAL UNIVERSITY}

\author{
I. V. Nizhenkovska, L. V. Yanitska, O. V. Stechenko, M. S. Vlasenko, T. P. Pradiy \\ National Medical University by O. O. Bohomolets
}

\begin{abstract}
Стаття присвячена аналізу викладання біологічної хімії студентам медико-психологічного факультету як частини нормативної дисципліни "Біологічна та біоорганічна хімія" на засадах європейської кредитно-трансферної системи.

The article is dedicated to the analysis of biological chemistry teaching in medical-psychological faculty as a part of the normative discipline "Biological and bioorganic chemistry" according to the foundations of European credit-transfer system.
\end{abstract}

Вступ. У вищих медичних навчальних закладах України біологічна хімія викладається протягом третього - четвертого семестрів і, поряд з іншими медико-біологічними дисциплінами, є основою для подальшого вивчення загальної патології та клінічних дисциплін, формування наукового світогляду лікаря. У зв'язку з цим курс біохімії включає наукові відомості, що стосуються насамперед біохімічних процесів, які мають місце в організмі здорової та хворої людини і засвоєння яких $є$ необхідною передумовою для оволодіння знаннями про біохімічні, молекулярні механізми як фізіологічних функцій, так і розвитку патологічних процесів. Незважаючи на професійну спрямованість тапевну профілізацію навчального матеріалу, що викладається, курс біохімії в системі вищих медичних закладів освіти зберігає характер фундаментальної дисципліни, яка забезпечує базову університетську освіту майбутнього фахівця [1].

Сучасні вимоги до випускників, в тому числі нових лікарських спеціальностей, як-то медичних психологів вищих медичних навчальних закладів, роблять необхідним більш ретельну та інформативну підготовку навчально-методичних матеріалів для студентів і викладачів.

Навчання за спеціальністю лікаря-психолога, безумовно, відрізняється від інших лікарських спеціальностей особливими індивідуальними і характероло- гічними якостями, а також особливою мотивацією до засвоєння базових теоретичних дисциплін.

Студенти, які навчаються за спеціальністю лікаряпсихолога, проявляють певні якості при навчанні [2]. Медико-біологічні дисципліни складають основу для розуміння системності зовнішнього середовища $\mathrm{i}$ структурно-функціональних закономірностей здорового та хворого організму, глибини і якості засвоєння даного матеріалу. Це було враховано кафедрою біоорганічної, біологічної та фармацевтичної хімії при складанні навчально-методичних матеріалів, тестових завдань в навчальному процесі на медико-психологічному факультеті.

Типова навчальна програма з дисципліни “Біологічна та біоорганічна хімія” для спеціальності “Медична психологія" створена співробітниками кафедри в 2010 році, охоплює викладання основних питань, які складають предмет сучасної біологічної хімії. Детально розглядаються: структура біомолекул та молекулярна організація клітинних структур, закономірності ферментативного каталізу, перетворення основних класів біомолекул, молекулярна біологія та генетика інформаційних макромолекул, молекулярні механізми спадковості та реалізації генетичної інформації, гормональна регуляція метаболізму та біологічних функцій клітин, біохімія спеціалізованих фізіологічних функцій [3]. 
Відповідно до фахової спрямованості медико-психологічного факультету, окремо висвітлено розділ “Біохімія нервової системи та нейромедіаторів”, предметом якого є вивчення складу та метаболізму нервової системи, а також фізіологічно активних сполук нейромедіаторного типу, нейрохімічні механізми дії лікарських препаратів, що застосовуються в неврології та психіатрії, та порушення обміну медіаторів і модуляторів головного мозку при психоемоційних або психічних розладах.

Основна частина. Психолого-дидактичні аспекти формування самостійно-пізнавальної діяльності студентів при вивченні біологічної хімії враховувались під час створення навчально-методичних розробок для самостійної роботи студентів (СРС) майбутніх лікарів-психологів. Важливе значення під час навчального процесу було приділено організації СРС, яка $\epsilon$ ефективним сучасним засобом навчання. Основними методами, які дозволяють ефективно організувати самостійну роботу студентів, є електронні підручники, навчальні посібники, тестові завдання та ситуаційні задачі.

Для успішного навчання студента позааудиторно необхідною компонентою є: 1) уміння самостійно формулювати й утримувати навчальну мету до іiі реалізації; 2) навчатися моделювати власну діяльність, тобто виділяти умови, важливі для реалізації мети; 3) розвивати увагу, пам'ять та удосконалювати процес мислення; 4) вміти оцінювати кінцеві та проміжні результати своїх дій; 5) мати необхідні навички та вміння для навчальної діяльності; 6) мати високий рівень особистої саморегуляції, високу самосвідомість, адекватну самооцінку, рефлективність, організованість, самостійність, а також сформованість вольових якостей.

Однак матеріали багатьох досліджень свідчать [4] про низький рівень студентів самостійно працювати. Формуванню здатності до самостійної навчальної діяльності допомагають не тільки умови, названі вище, але й позитивна навчальна мотивація та позитивне ставлення до навчання.

3 метою з'ясування психологічних особливостей та здібностей студентів медико-психологічного факультету нами було проведено анкетування студентів 1-го та 2-го курсів, які вивчають дисципліну “Біологічна та біоорганічна хімія". В ході анкетування студентам було запропоновано відповісти на питання, щодо самооцінки власного базового рівня підготовки для вивчення дисципліни, про важливості і важкості сприйняття різних тем, ставлення до методики викладання дисципліни на кафедрі, якості і сумлін- ності роботи викладачів, про можливість самостійно піготуватись до практичного заняття з використанням питань, наданих викладачем, електронних носіїв і методичних розробок для СРС, розроблених кафедрою.

Аналіз результатів опитування показав, що початковий рівень підготовки достатнім для вивчення дисципліни “Біологічна та біоорганічна хімія” на 1 курсі вважають $15 \%$ студентів, а на другому курсі - $57 \%$.

Найбілыш складними темами з дисципліни “Біологічна та біоорганічна хімія" виявились на 1 курсі “Амінокислоти”, а на 2 курсі - “Цикл трикарбонових кислот” та “Коферментні функції вітамінів".

78 \% студентів задовольняє рівень викладання дисципліни “Біологічна та біоорганічна хімія", проведення практичних занять з дисципліни, в той же час лише $68 \%$ студентів використовує матеріал лекцій при підготовці до практичних занять.

Опитування показало також, що 64 \% студентів бажають та отримують завдання від викладача для самостійної роботи, в змозі підготуватись самостійно до практичного заняття та мають досвід самостійного опрацювання матеріалу з дисципліни “Біологічна та біоорганічна хімія" на 2 курсі.

Проте тільки 54 \% студентів використовує методичні розробки для СРС, створені кафедрою, та користуються електронними носіями для самостійної підготовки до практичних занять.

Основним побажанням щодо покращення викладання дисципліни “Біологічна та біоорганічна хімія” з точки зору студентів була необхідність використання більшої кількості демонстративних матеріалів, презентацій та відеофільмів.

3 урахуванням результатів анкетування студентів медико-психологічного факультету співробітниками кафедри при створенні методичних розробок основну увагу зосередили на СРС. Методичні розробки були присвячені саме тим темам, які виявились найважчими для засвоєння студентами відповідного факультету. Структурований зміст даних матеріалів включає: актуальність теми, перелік конкретних цілей, перелік базових знань, вмінь, навичок, необхідних для вивчення теми, завдання для самостійної роботи під час підготовки до заняття, перелік основних термінів, параметрів, характеристик, необхідних для засвоєння студентом при підготовці до заняття, перелік теоретичних питань до заняття, практичні роботи, які виконуються на занятті, зміст теми у вигляді структурно-логічної схеми, матеріали для самоконтролю (задачі, тестові завдання формату А та В) та самостійної підготовки студентів. 
Для підвищення рівня організації самостійної роботи студентів медико-психологічного факультету відповідно до вимог Болонського процесу кафедрою в навчальний процес були впроваджені такі заходи:

1) формування у студентів потреби й інтересу до самостійної роботи (підготовка конспекту до кожного заняття, який допомагає краще засвоїти матеріал та обов'язково оцінюється викладачем);

2) урахування інтересів та можливостей студентів під час визначення завдань для індивідуальної самостійної роботи;

3) урахування групових особливостей студентів (рівень інтелектуального розвитку, провідний тип темпераменту, мотив навчальної діяльності і т. д.);

4) шляхом розробок індивідуальних творчих завдань для самостійної роботи студентів над проблемними темами курсу під керівництвом досвідченого викладача;

5) створення необхідного методичного матеріалу для організації самостійної роботи студентів;
6) керівництво самостійною роботою студентів і надання вчасної допомоги для усунення недоліків (викладачем надаються перелік теоретичних питань, джерела додаткової літератури та консультації);

7) оцінювання індивідуальної СРС в балах, відповідно до кредитно-модульної системи і врахування під час оцінювання модулів та дисципліни в цілому.

Після впровадження кафедрою додаткових заходів для організації СРС початковий рівень підготовки для вивчення дисципліни "Біологічна та біоорганічна хімія" від 15 \% на 1 курсі зростає до 57 \% на другому курсі. Також спостерігається позитивна динаміка в зростанні відсотка студентів, які володіють навичками самостійної роботи, необхідними для успішного вивчення зазначеної дисципліни. На відміну від студентів 1 курсу, де навичками СР володіють не більше 30 \% осіб, на 2 курсі цей показник зростає до $64 \%$ (рис.1).
Puc. 1. Визначення вихідного рівня знань та навичок СРС серед студентів 1 та 2 курсів медико-психологічного факультету (за результатами анкетування).

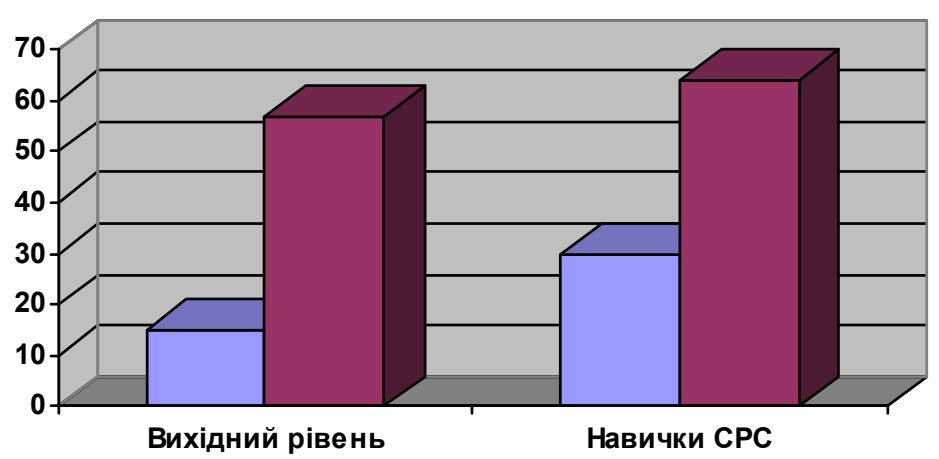

2. Відповідно до результатів проведеного аналізу внесені корективи в організацію навчально-методичної роботи кафедри з активації СРС медико-психологічного факультету.

3. 3 метою оптимізації викладання дисципліни “Біологічна та біоорганічна хімія" на відповідному факультеті та для покращення підготовки цієї категорії студентів до складання "КРОК-1". Постала необхідність підготовки і видання навчального посібника, в якому будуть враховані особливості викладання і вивчення дисципліни майбутніми медичними психологами.

медико-психологічного факультету.

4. Максименко С. Д. Психологія в соціальній тапедагогічній практиці : навчальний посібник / С. Д. Максименко. - 1998.

5. Величко Т. Г. Особливості організації навчання студентів в умовах нових педагогічних технологій / Т. Г. Величко // Проблеми освіти : наук.-метод. зб. - К. : Наук.-метод. центр вищої освіти, 2003. - Вип. 31. - 360 с. - С. 90-97. 